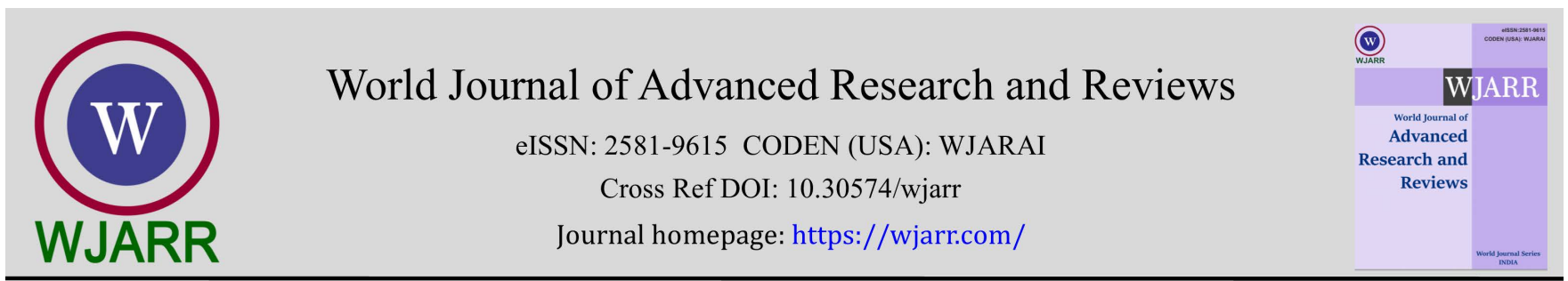

(RESEARCH ARTicle)

\title{
Socio-cultural business environment factors and entrepreneurial performance: Experience from Nigeria small and medium enterprises
}

\author{
Ojelade $\mathrm{MO}{ }^{1}$, Yinus SO ${ }^{2}$, Ishola JA ${ }^{1}$ and Opaleye $\mathrm{MA}^{3}$ \\ ${ }^{1}$ Department of Business Administration, Thomas Adewumi University, Oko, Kwara state, Nigeria. \\ 2 Department of Accounting, Ladoke Akintola University of Technology, Open and Distance Learning Centre, Ogbomoso, \\ Oyo State, Nigeria. \\ ${ }^{3}$ Department of Business Administration, Precious Cornerstone University, Ibadan, Oyo state, Nigeria.
}

World Journal of Advanced Research and Reviews, 2022, 13(03), 013-021

Publication history: Received on 19 January 2022; revised on 27 February 2022; accepted on 01 March 2022

Article DOI: https://doi.org/10.30574/wjarr.2022.13.3.0180

\begin{abstract}
The study examined the impact of socio-cultural business environment factors on the performance of small and medium-scale enterprises (SMEs) in the Ibadan metropolis. The paper sets out to weigh the influence of variables such as the family system, gender, level of income, education, and religion on the making of successful entrepreneurs. The study made use of the questionnaire, which was well structured and worded to elicit the desired responses from the respondents. This was administered to 300 respondents, although 275 copies of the questionnaire were properly filled out and returned. To analyze the collected data and determine the strength of the relationship between socio-cultural factors and entrepreneurial performance, the Multiple Regression statistical tool was used. Findings from the results $(\mathrm{R} 2=0.845 ; \mathrm{F}$-value $=524.38, \mathrm{P}>\mathrm{z} \mid=0.0001)$ revealed that socio-cultural business environment factors positively influence the performance of the selected enterprises. It is recommended that relevant authorities work on the socioeconomic sector of the economy so as to increase the capacity of potential entrepreneurs. An enabling environment should be created by the government to give businesses room to thrive, so as to increase the drive for entrepreneurship development.
\end{abstract}

Keywords: Socio-cultural business environment factors; Performance; Small and medium scale Enterprises; Entrepreneurial; Entrepreneurship

\section{Introduction}

The term "small and medium-scale enterprise" encompasses a broad spectrum of definitions. Different organizations and countries set their own guidelines for defining the concept, often based on headcount, sales, or assets. While Egypt defines SMEs as having more than 5 and fewer than 50 employees, Vietnam considers the concept to have between 10 and 300 employees. The World Bank defines SMEs as enterprises with a maximum of 300 employees, \$15 million in annual revenue, and \$15 million in assets. The Inter-American Development Bank, meanwhile, describes SMEs as having a maximum of 100 employees and less than $\$ 3$ million in revenue. The SME sector is the backbone of the economy in high-income countries, but is less developed in low-income countries. The Organization for Economic Co-operation and Development (OECD) reports that more than 95\% of enterprises in the OECD area are SMEs. These enterprises account for almost $60 \%$ of private sector employment, make a large contribution to innovation, and support regional development and social cohesion. Also, in low-income countries, the SME sector makes a critical contribution to GDP and employment.

\footnotetext{
${ }^{*}$ Corresponding author: Yinus SO

Department of Accounting, Ladoke Akintola University of Technology Ogbomoso, Open and Distance Learning Centre, Oyo State, Nigeria.

Copyright $(2021$ Author(s) retain the copyright of this article. This article is published under the terms of the Creative Commons Attribution Liscense 4.0.
} 
In Nigeria, small-scale businesses represent about $90 \%$ of the industrial sector in terms of the number of enterprises. They also account for $70 \%$ of national industrial employment if the threshold is set at 10-50 employees, contribute $10 \%$ of manufacturing output, and a meager 1\% of gross domestic product (GDP) in 2010 (Ajayi, 2012). Similarly, they have also contributed significantly to economic development through employment, job creation, and sustainable livelihood (Nigeria Investment Promotion Commission, 2013). In spite of the major role, the significance, and the contributions of small-scale enterprises to the national economy, this set of enterprises is still battling with many problems and certain constraints that exist in promoting their development and growth. For instance, an International Labour Organization (ILO) study shows that insufficient entrepreneurial talent affects the development of small-scale manufacturing and processing industries. While large-scale industries are established with expatriate capital, small-scale industries need to have a domestic entrepreneurial and industrial base. Other problems that hinder the advancement of small-scale enterprises are the persistent low level of technology, the shortage of adequate entrepreneurial skills among operators, and the absence of an effective management technique. Discussion of a change in the level of technology and its impact on the Nigerian industries has focused on large firms (i.e., capital-intensive, high-technology sectors). The focus on this change in small-scale firms is relatively small. Small-scale enterprises tend to concentrate on traditional industries where low entry barriers, low minimum production scales, and a relatively large labor force are the potential advantages. However, the traditional industries have not been immune to the recent technological revolution taking place in the field (Adubifa, 1990). The geneuity of this claim calls for empirical investigation in the recent era of techpreneurship.

The socio-economic status of the country has considerably affected the development and improvement of certain sectors. Recent times have witnessed a number of strategies and activities like sharply expanded programmes, techniques and innovations in agricultural programmes in Nigeria in order to address the deteriorating socio-economic situation. Universities, research institutes, and private-sector organizations are the most important institutions involved in technical entrepreneurship, which is one of the major sources of wealth, power, and employment generation in developed countries. Unfortunately, the absence of a viable industrial and private sector, the deficiencies of existing infrastructure and the dominance of foreign-based multinational companies tend to have a limiting effect on the capacity to create, foster and nurture indigenous enterprises in Nigeria. Identifying and supporting the activities of potential and existing entrepreneurs has become a major concern for an increasing number of governments in developed and developing countries. Public policies are designed in developing countries to increase the pool of entrepreneurs and to promote the formation of certain types of businesses at the micro and small-scale levels, which foster technological activities (Litvak, 2002). Most developing countries' governments, including Nigeria's, have been chastised for failing to pay enough attention to the need for faster economic growth and for failing to capitalize on their citizens' abilities for technological innovation and entrepreneurship (Anamekwe, 2001).

\subsection{Statement of the Problem}

It is a clear fact that many micro, small, and medium-scale enterprises are dying out owing to a lack of financial support from the government and other citizens. Evidence from the literature (Mils, 1990; World Bank, 2002; Udoviki, 2018; United Nations Industrial Development Organization, 2013) reveals that the major preoccupation of all developing countries these days is simply how to improve the social, economic, and political status of their people. This involves the improvement of the living standards of the mass of the low-income population and making the process selfsustaining. Improving the living standards of people involves the setting of priorities in the mobilization and use of resources available. In some rural areas, the working and living conditions of women, for instance, have not been able to be ameliorated by many recent programmes designed to improve their economic status. Many scholars have pointed out the detrimental effects on women of technological and socio-economic changes in the process of development. There has not been enough consideration and enough provisions for some rural entrepreneurs in the development process. Many of these entrepreneurs are left out of the provisions of the government toward the advancement of their enterprises. The design and methods used by some studies, like Anyadike, Emeh, and Ukah (2012) and Arasti, Pasvishe, and Motavaseli (2012), vary greatly. The inconsistencies in the results of previous studies indicate a research gap that this study tends to examine. This study remains germane by examining the effects of socio-cultural business environment factors on entrepreneurial performance. In an attempt to achieve the aim of this study, the following questions were raised:

- Is there any relationship between gender and entrepreneurial performance?

- Does the income level of a SME operator influence entrepreneurial performance?

- Is there any relationship between the level of education and entrepreneurial performance?

- Did religious practice have any effect on entrepreneurial performance? 


\subsection{Research hypothesis}

Ho: Socio-cultural business environment factors does not have any significant effect on Entrepreneurial Performance

\section{Theoretical Framework and Literature}

\subsection{Theoretical Framework of the Study}

The construct of this study is embedded in the socio-cultural approach. This is based on the fact that the socio-cultural approach involves the total use of cultural influence to develop entrepreneurship. Value-based entrepreneurial culture refers to the sum total of dynamic and innovative ways and means in which entrepreneurs respond to changes in the environment. It further refers to the spirit of openness, conformity, trust, authenticity, proactively, creativity, innovation, collaboration, experimentation, and conformity. Without a doubt, experts and scholars in the field of entrepreneurship development have emphasized the importance of socio-cultural factors in people's environments and backgrounds in the development of entrepreneurship and business performance (Rajesh, 2006).Gibb (1987), in consonance with this, suggested that entrepreneurial culture, which is a product of culture, is the set of values, attitudes, and beliefs that support the exercise in the community of independent entrepreneurial behavior in a business context. These values form an entrepreneurial and corporate culture where entrepreneurs work effectively and efficiently in order to contribute to economic development. The socio-cultural components of the general environment include demographic factors, general behaviour, attitudes, and beliefs of the people in that society. This therefore indicates that social-cultural changes and trends influence entrepreneurship development. In line with this, authors have pointed out the importance of socio-cultural factors in the development and nurturing of entrepreneurship growth. For instance, it helps in the final decision to create a new business, which involves entrepreneurship, and entrepreneurship is also embedded in a social context (Rajesh, 2006). This, therefore, makes it possible to view entrepreneurship development as a societal phenomenon rather than a purely economic activity. This is supported by the fact that Japan has taken a cultural approach to developing its entrepreneurship over the years. For example, culture has helped both Japan and the USA with their entrepreneurial performance (Arowomole, 2000). Research has asserted that Japanese culture or tradition emphasizes group action and cooperation and business and government cooperation, which has encouraged entrepreneurs. Thus, the importance of culture should not be neglected in the development of entrepreneurship. Countries that recognize the uniqueness of their socio-cultural environment are capable of breaking frontiers and, thus, achieving better entrepreneurial development results.

\subsection{Socio-Cultural Business Environment Factors Concept}

Socio-cultural business environment factor consists of both the social system and the culture of a person in an environment or community toward day-to-day business activity. It refers primarily to man-made intangible elements that affect people's behaviour, relationships, perceptions, ways of life, and survival in the community and nation as a whole. In other words, the social-cultural environment consists of all the elements, conditions, and influences that shape the personality of an individual and potentially affect his attitude, disposition, behaviour, decisions, and activities. Such elements include beliefs, values, attitudes, habits, forms of behaviour and lifestyles of people as developed from cultural, religious, educational and social conditioning (Bennett and Kassarjian, 1972; Adeleke, Oyenuga and Ogundele,2003). These elements are learned and are shared by a society and are transmitted from generation to generation within that society. Thus, social-cultural factors in relation to entrepreneurship activities can be defined as consisting of all the elements of the social system and culture of a person which positively or negatively affect and influence entrepreneurial emergence, behaviour, and performance, as well as entrepreneurship development in general. All such elements that condition the values, thinking, and actions of an individual with respect to entrepreneurship comprise the socialcultural factors of entrepreneurship development.

\subsection{Social Cultural factors and Entrepreneurial Activity}

Embeddedness and relational networks Understanding entrepreneurship as a social phenomenon allows us to draw on the well-developed more general literature on social capital and social networks. The concept of social capital is arguably one of the most successful "exports" from sociology to the other social sciences (Portes, 2000). Jacobs (1962) and Loury (1977), who developed the individualistic and economic conception, are credited with coining the term "social capital" (Anderson and Jack, 2002; Anderson et al., 2007). Social capital is defined as the tangible and virtual resources that facilitate actors' attainment of goals and that accrue to them through social structure (Portes, 1999). Given the central proposition that networks of relationships constitute a valuable resource (Nahapiet and Ghoshal, 1998), many of the insights of social capital theory relative to entrepreneurial activity can be found in the social network literature (Casson and Della Giusta, 2007). In general terms, social networks are defined by a set of actors (individuals and organizations) and a set of linkages between those actors (Brass, 1992). Social networks are the relationships 
through which one receives opportunities to use financial and human capital-relationships in which ownership is not solely the property of an individual, but is jointly held among the members of a network (Burt, 1992). Social networks are also a set of relationships that can define the perception of a community, whether a business community or a more general notion of community in society (Anderson and Jack, 2002). Thus, society, in the abstract sense, is a series of connected or "tied" nodes (Narayan and Pritchett, 1999). This broad conception of social networks and social capital implies that the dynamics of economic exchange are socially embedded (Granovetter, 1985; Portes and Sensenbrenner, 1993). As distinct from rational choice perspectives, the social embeddedness perspective emphasizes that, in embedded contexts, entrepreneurial agency, that is, the ability to garner entrepreneurial ideas and the resources to develop them, is shaped by implicit norms and social mores. Thus, social capital is conceptualized as a set of resources embedded in relationships (Burt, 1992). This idea raises interesting questions revolving around the entrepreneurial applications of social capital, in particular, in relation to some less desirable consequences. For instance, the exploitation of social capital by any one person or entrepreneur, even within contextual rules, if any, implies both winners and losers (Anderson and Jack, 2002). Related to this idea, Portes and Landolt (2000) identified four negative consequences of social capital: exclusion of outsiders; excess claims on group members; restrictions on individual freedoms; and downward levelling of norms.

\subsection{Cultural factors and Entrepreneurial activity}

Because societies are endowed by nature with different physical environments, members of society must adopt environmentally relevant patterns of behavior to achieve success. These environmentally relevant patterns of behavior lead to the formation of different cultural values in different societies, some of which influence the decision to create new businesses. Thus, culture, as distinct from political, social, technological, or economic contexts, has relevance for economic behavior and entrepreneurship (Shane, 1993). One of the difficulties in examining the cultural effects and effects in relation to entrepreneurial activity is the lack of a precise and commonly understood definition of culture (McGrath et al.,1992). Anthropologists suggest that culture is related to the ways in which societies organize social behavior and knowledge (Hall, 1973; Kroeber and Parsons, 1958). Cultural values are defined as the collective programming of the mind which distinguishes the members of one human group from another and their respective responses to their environments (Hofstede, 1980). Several studies have stressed the influence of cultural factors on entrepreneurship from different perspectives. In their literature review, Hayton et al. (2002) link culture and entrepreneurship to three broad streams of research. The first focuses on the impact of national culture on aggregate measures of entrepreneurship, such as national innovative output or new businesses created. The second stream addresses the association between national culture and the characteristics of individual entrepreneurs. The third explores the impact of national culture on corporate entrepreneurship. Accordingly, when an individual creates a business in a specific cultural environment, that business reflects that cultural environment's characteristics, for example, strategic orientation and growth expectations for the business.

Much of the research in entrepreneurship that considers cultural variables has followed Hofstede's (1980, 2001) seminal work showing how culture is manifested in various forms and how cultural values at individual or societal levels are influenced by national culture. According to this view, cultural differences across societies can be reduced to four quantifiable dimensions: uncertainty avoidance, individualism, masculinity, and power distance. The dimension of uncertainty avoidance represents a preference for certainty and discomfort with unstructured or ambiguous situations. Individualism stands for a preference for acting in the interest of oneself and immediate family, as distinct from the dimension of collectivism, which stands for acting in the interest of a larger group in exchange for their loyalty and support. Power distance represents the acceptance of inequality in position and authority between people. Masculinity stands for a belief in materialism and decisiveness rather than service and intuition. Using Hofstede's (1980) concept of culture, researchers have in general hypothesized that entrepreneurship is facilitated by cultures that are high in individualism, low in uncertainty avoidance, low in power-distance, and high in masculinity (Hayton et al., 2002).

\subsection{Empirical Review}

The findings of Crant (2016) revealed that having entrepreneurial parents impacts positively on entrepreneurial intention. Muhammad Azam Roomi (2010) studied the variables contributing to the growth of women-owned enterprises in the Islamic Republic of Pakistan from the perspectives of personal resources, firm characteristics, human resource strategy, and favorable women-friendly social values and cultural traditions. Statistical analysis and in-depth interviews confirmed that women entrepreneurs' personal resources and social capital have a significant role in their business growth. It further discovers that moral support from immediate family, independent mobility, and being allowed to meet with the opposite gender play a decisive role in both the sales and employment growth of womenowned enterprises in an Islamic country like Pakistan. Also, Jill Kickul et al. (2018) studied entrepreneurial intention for the purpose of understanding the reasons behind the gaps in entrepreneurial intention amongst adolescents. Specifically, the research aimed to test multiple models that analyze direct and indirect relationships between work and 
leadership experience, the presence of a parental role model, self-efficacy, and interest by adolescents in entrepreneurship. Questionnaires were used to obtain data from the sample, which consisted of 5,000 middle and high school students in four geographic states or regions (New England, Illinois, California, and Texas/Florida/Tennessee). A focus group interview was also conducted in order to obtain qualitative data as the study adopted the mix method. Part of the findings of the research revealed that having an entrepreneurial mother or father was found to have a significant and positive effect. As a result, the positive impact of family background on entrepreneurial intention is confirmed.

Evidence from literature establishes that education, religion, and family background, which when put together form the socio-cultural business environment, all have a positive impact on entrepreneurial intention. This present study focuses on religion, educational background, gender, and level of income as components of socio-cultural business environment factors and examines their effects on entrepreneurial performance, especially amongst young people. It is expected that the socio-cultural business environment should be given adequate attention and manipulated towards boosting the supply of entrepreneurs. This research aims to fill that void.

\section{Methodology}

The study made use of a survey approach with a simple random sampling technique where the entrepreneurs/ownermanagers of small firms and policy makers in Ibadan metropolis were selected as the targeted population of this study. The sampled respondents of the study comprise selected SME operators (entrepreneurs) who are registered with the Oyo state government. With the aid of a random sampling technique, 300 entrepreneurs were selected from the population of registered SMEs in Ibadan metropolis. Of this number, only two hundred and seventy-five (275) were properly filled, returned, and found useful for the purpose of the study. The data collected was analysed using descriptive statistics like table and percentage, while the formulated hypotheses were analysed using inferential statistics like multiple regression analysis at a $95 \%$ confidence level.

\subsection{Model Specification and Measurements Variables}

The independent variables are socio-cultural business environment factors and are hypothesized based on gender, level of income, age structure, educational background, and religion of the SME operator. The dependent variable is entrepreneurial performance and is measured based on SME operation efficiency. Mathematically, the model is expressed as follows

$$
E P=\left(a+b_{1} x_{1}+b_{2} x_{2}+b_{3} x_{3} \ldots . .+b_{4} x_{4}+\lambda\right)
$$

Where,

$\mathrm{EP}=$ Entrepreneurial Performance,

$\mathrm{X}_{1}$ to $4 \mathrm{X}_{1}=$ socio-cultural business environment factors (Gender, Level of income , Educational background, and Religion. $\alpha_{0}=$ Intercept,

$\mathrm{b}_{1}-\mathrm{b}_{4}=$ Regression Coefficient, $\lambda=$ Stochastic error term.

\section{Results and discussion}

\subsection{Descriptive Analysis of Social-Economic Profile of Respondents}

Analysis in Table 1 shows that $37 \%$ of respondents were male while $63 \%$ were female. $23 \%$ had no formal education, $14 \%$ had primary education,155 had secondary education and $48 \%$ had tertiary education. On the pre-occupation of the respondents, $31 \%$ were into buying and selling, $10 \%$ were civil servant, $14 \%$ were into confectionery, $8 \%$ into textiles while $17 \%$ were into teaching profession. As per the income level of the respondents, $37 \%$ had income level of above N80,000 per month, 31\%, 15\% and 17\% had income levels of above N100,000, N120,000 and N150,000 respectively.

\subsection{Regression Analysis of Socio-Cultural Business Environment Factors Effect on Entrepreneurial Performance}

Based on the results in table 2, analysis indicates that socio-cultural business environment factors such as gender, level of income, and educational background are significant and positively related to entrepreneurial performance. with the implication that a unit increase in socio-cultural business environment factors such as gender, level of income, 
educational background, and religion will increase entrepreneurial performance by $0.4,1.2$, and 0.8 units, respectively. The result of the analysis shows that as the identified socio-cultural business environment factors like gender, level of income, and educational background increase, performance also increases. Religion exerts a positive relationship with entrepreneurial performance, but not significant. This implies that religious practice has no significant effect on entrepreneurial performance. More so, following the result of the analysis (Table 2), the null hypothesis is that sociocultural business environment factors do not have any significant effect on entrepreneurial performance. The coefficient of determination (R2) of 0.845 (approximately 85\%) and also supported by the high value of adjusted (R2) at 0.843 (approximately 84\%), the result indicates that independent variables incorporated into this model have been able to reveal that the predictor variables (socio-cultural business environment factors) make a significant contribution to entrepreneurial performance. The F-value (542.38) and P-value (0.001) also confirmed the significance of the model. Because the constant and coefficient are statistically significant, the null hypothesis is rejected while the alternative hypothesis is accepted. With an indication that socio-cultural business environments have a significant effect on entrepreneurial performance.

Table 1 Descriptive Analysis of Social-Economic Profile of Respondents

\begin{tabular}{|c|c|c|}
\hline Variables & Frequency & Percentage \\
\hline \multicolumn{3}{|l|}{ Gender } \\
\hline Male & 102 & 37 \\
\hline Female & 173 & 63 \\
\hline Total & 275 & 100 \\
\hline \multicolumn{3}{|c|}{ Educational Background } \\
\hline No formal Education & 64 & 23 \\
\hline Primary education & 38 & 14 \\
\hline Secondary education & 41 & 15 \\
\hline Tertiary education & 102 & 48 \\
\hline Total & 275 & 100 \\
\hline \multicolumn{3}{|l|}{ Pre-occupation } \\
\hline Trading & 84 & 31 \\
\hline Civil servant & 29 & 10 \\
\hline Confectionery & 38 & 14 \\
\hline Textile & 78 & 8 \\
\hline Teaching & 46 & 17 \\
\hline Total & 275 & 100 \\
\hline \multicolumn{3}{|l|}{ Income level/Month } \\
\hline Above N80,000 & 102 & 37 \\
\hline Above N100,000 & 85 & 31 \\
\hline Above N120,000 & 41 & 15 \\
\hline Above N150,000 & 47 & 17 \\
\hline Total & 275 & 100 \\
\hline
\end{tabular}


Table 2 Regression Analysis of Socio-Cultural Business Environment Factors Effect on Entrepreneurial Performance

\begin{tabular}{|c|c|c|c|c|}
\hline Variables & B & E $\beta$ & Beta & t-value \\
\hline Constant & 6.540 & 0.746 & - & 7.542 \\
\hline X1 & 0.427 & 0.127 & 0.138 & $3.148^{*}$ \\
\hline X2 & 1.154 & 0.634 & 0.243 & $2.542^{*}$ \\
\hline X3 & 0.823 & 0.415 & 0.216 & $2.538^{*}$ \\
\hline X4 & 0.387 & 0.204 & 0.187 & 1.054 \\
\hline R2 & 0.845 & AdjR2 & 0.842 & \\
\hline F-Value & 542.38 & P-Value & 0.001 & \\
*Sig. at 0.05 level of significance; Source: Data Analysis, 2021.
\end{tabular}

\section{5. conclusion}

The result from this study indicates that the four salient variables of socio-cultural business environment factors identified in the work account for $84 \%$ of the total variation in explaining the impact of socio-cultural business environment factors on the performance of the selected enterprises. Findings indicate that religious practice has no significant effect on entrepreneurial performance. However, three of these explanatory variables were found to have significantly contributed to the dependent variable (performance), and the significant variables were gender distribution of entrepreneurs $\left(\mathrm{X}_{1}\right)$, educational background (X2), and level of income of sampled SME operators ( $\left.\mathrm{X}_{3}\right)$. This result is in line with the findings of Bygrave (1989) that there is a significant relationship between socio-economic factors and performance in terms of growth in earnings and or profitability.

\section{Recommendations}

Based on the findings of the study, it was observed that socio-cultural business environment factors positively influence the performance of the selected enterprises. In view of the above findings, it is recommended that relevant authorities work on the socio-economic sector of the economy so as to increase the capacity of potential entrepreneurs. An enabling environment should be created by the government to give businesses room to thrive, so as to increase the drive for entrepreneurship development.

\section{Compliance with ethical standards}

\section{Acknowledgments}

We thank all the anonymous referees for their useful suggestions.

\section{Disclosure of conflict of interest}

No conflict of Interest.

\section{References}

[1] Adeleke, A. Oyenuga, 0.O. and Ogundele, OJ.K. Business Policy and Strategy. Mushin, Lagos: Concept Publications Limited. (2003).

[2] Adubifa, A. Technology Policy in Nigeria (1990): (A Critical Appraisal of the Industrial Sector); Nigerian Institute of Social and Economic Research (NISER): Ibadan, Nigeria. 1990; 37-90.

[3] Ajayi, O.A (2012) "Development of Small-Scale Industries in Nigeria". Being Paper Presented at Workshop on Grassroots Advocacy and Economic Development. September (2012); 11-13.

[4] Akeredolu-Ale, E.O. The Underdevelopment of Indigenous Entrepreneurs in Nigeria, Ibadan: University Press, (1975); 14-16. 
[5] Aldrich H. E., Cliff J. E. The pervasive effects of family on entrepreneurship: Toward a family embeddedness perspective. Journal of business venturing. (2003); 18(5): 573-596.

[6] Anamekwe, C. (2001) "Micro and Small-Scale Industries in Nigeria: Problems and Prospects". Being paper presented at Workshop on Grassroots Advocacy and Economic Development. September (2001); 11-13.

[7] Altinay, L. The relationship between an entrepreneur's culture and the entrepreneurial behaviour of the firm. Journal of Small Business and Enterprise Development. 2008; 15(1): 111-129.

[8] Altinay, L., Wang, C. L. The influence of an entrepreneur's socio-cultural characteristics on the entrepreneurial orientation of small firms. Journal of Small Business and Enterprise Development, (2011); 18(4): 673-694.

[9] Alwis, W. D., Senathiraja, R. The impact of socio-cultural background of the entrepreneur on management and business practices of selected small and medium scale businesses in Sri Lanka. In 9th International conference on Sri Lanka Studies, November. 2003; 28-30.

[10] Anyadike N., Emeh I.E.J ,Ukah F.O. Entrepreneurship development and employment generation in Nigeria: Problems and prospects. Universal Journal of Education and General Studies, 2012; 4(1): 88-102.

[11] Arasti Z., Pasvishe F. A., Motavaseli M. (2012). Normative Institutional Factors Affecting Entrepreneurial Intention in Iranian Information Technology Sector. Journal of Management and Strategy. (2012); 3(2): 16-25.

[12] Ayatse, F. A. Driving Entrepreneurship Education in Nigeria: Issues and Challenges. International Journal of Business and Management Review. (2013); 4(1): 83-90. Azim, M. T. Socio-cultural environment for entrepreneurship development in Bangladesh. Journal of Bangladesh Studies. (2008); 10(1): 51-60.

[13] Boggs, W.B. TQM and organizational culture: a case study. The Quality Management Journal. (2004); 11(2): 4252.

[14] Boyd N., Vozidis G. The influence of self-efficacy on the development of entrepreneurial intentions and actions. Entrepreneurship theory and practice. 1994; 18: 63-63.

[15] Bwisa H. M., Ndolo J. M. Culture as a factor in entrepreneurship development: A case study of the Kamba culture of Kenya. International Journal of Business Management, (2011); 1(1): 20-29.

[16] Davidsson, P., Honig, B. The role of social and human capital among nascent entrepreneurs. Journal of business venturing, (2003); 18(3): 301-331.

[17] De Noble, A., Galbraith, C. S., Singh, G., Stiles, C. H. Market justice, religious orientation, and entrepreneurial attitudes. Journal of Enterprising Communities: People and Places in the Global Economy, (2007); 1(2): 121-134.

[18] Dinis A., do Paço, A., Ferreira J., Raposo, M., Gouveia Rodrigues R. Psychological characteristics and entrepreneurial intentions among secondary students. Education + Training, (2013); 55(8/9): 763-780.

[19] Dolinsky A. L. The Effects of Education on Business Ownership: A Longitudinal Study of Women. Entrepreneurship: Theory and Practice, (1993); 18(1): 43-53. Dodd S. D., Seaman P. T. Religion and enterprise: An introductory exploration. Entrepreneurship theory and practice, (1998); 23: 71-86.

[20] Duru MEntrepreneurship Opportunities and Challenges in Nigeria. Business and Management Review, (2011); 1(1): 41-48.

[21] Gree A., Thurnik, C. Firm selection and industry evolution: the post country performance of new firm. Journal of Evolutionary Economics. (2003);4(4): 243-264.

[22] Hayton J. C., George, G., Zahra, S. National culture and entrepreneurship: A review of behavioral research. Entrepreneurship Theory \& Practice. 2002;26(4): 33.

[23] Kalkan M., Kaygusuz C. The Psychology of Entrepreneurship. Edited by Thierry Burger-Helmchen, (2012); 1.

[24] Kickul J., Wilson F., Marlino D., Barbosa S. D. Are misalignments of perceptions and self-efficacy causing gender gaps in entrepreneurial intentions among our nation's teens? Journal of Small Business and Enterprise Development. (2008); 15(2): 321-335.

[25] Kirkwood J. Igniting the entrepreneurial spirit: is the role parents play gendered? International Journal of Entrepreneurial Behavior \& Research, 2007;13(1): 39-59.

[26] Kuratko D. F., Montagno R. V. The intrapreneurial spirit. Training and Development Journal. 1989;43(10): 83-85

[27] Levent B.T., Masurel E., Nijkamp P. Diversity in entrepreneurship: Ethnic and female roles in urban economic life. International Journal of Social Economics. 2003;30(11): 1131-61. 
[28] Lucas Jr, R. E. On the size distribution of business firms. The Bell Journal of Economics. 1978; 508-523.

[29] McClelland D.C. The Achieving Society, Van Nostrand, Princeton, NJ. Morrison, A. (2000). Entrepreneurship: What triggers it? International Journal of Entrepreneurial Behavior \& Research. 1961; 6(2): 59-71.

[30] Nikolova E., Simroth D. Does cultural diversity help or hinder entrepreneurs? Evidence from eastern Europe and central Asia 2013; 158.

[31] Palich L. E., Bagby D. R. Using cognitive theory to explain entrepreneurial risk-taking: Challenging conventional wisdom. Journal of business venturing. 1995;10(6): 425-438.

[32] Shane, S. Prior knowledge and the discovery of entrepreneurial opportunities. Organization science. 2000; 11(4): 448-469.

[33] Schultz T. W. Investment in entrepreneurial ability. The Scandinavian Journal of Economics. 1980; 437-448.

[34] M.G. \& D.F. Twomey. The long-term Supply of Entrepreneurs: Students' Career Aspirations in Relation to Entrepreneurship. Journal of Small Business Management. 1988;26: 35-13. 